\section{NEW ANTIBIOTICS FROM CYLINDROCARPON SP.}

Sir:

In the course of screening antifungal metabolites, we found a species of Cylindrocarpon (strain PF-60) which produced seven compounds belonging to the roridin group. ${ }^{1)}$ Two of the seven were obtained in very poor yield and not investigated in detail. One compound was confirmed to be roridin $\mathrm{H}(\mathrm{I}){ }^{2)}$ Characterization of the remaining four new compounds is described in this paper.

The fungus was fermented at $28^{\circ} \mathrm{C}$ for 91 hours under aeration at 15 liters/min and agitation at 300 r.p.m. in a 30 -liter jar fermentor containing 20 liters of medium composed of $200 \mathrm{~g} /$ liter boiled potato extract and $2 \%$ sucrose. The fermentation broth was extracted with ethyl acetate giving an antifungal oily residue. The residue was separated into seven components by silica gel chromatography (benzene-ethyl acetate, $2: 1$ ) and preparative TLC on silica gel (benzene acetone, $2: 1)$.

Isororidin E (II) was crystallized from ethyl acetate as colorless prisms: $\mathrm{C}_{29} \mathrm{H}_{38} \mathrm{O}_{8} ;$ m.p.
$200 \sim 202^{\circ} \mathrm{C} ; \quad \mathrm{M}^{+} 514 ;[\alpha]_{\mathrm{D}}^{24}-65.1^{\circ}\left(\mathrm{CHCl}_{3}\right)$; $\nu_{\mathrm{max}}^{\mathrm{CHC1} 13} 3757(\mathrm{OH}), 1713(\mathrm{C}=\mathrm{O}), 1644(\mathrm{C}=\mathrm{C})$, and $1598 \mathrm{~cm}^{-1}(\mathrm{C}=\mathrm{C}) ; \lambda_{\max }^{\mathrm{EtOH}} 223 \mathrm{~nm}(\varepsilon 24,000)$ and $262(16,000)$. Although these data and the NMR data closely resemble those of roridin E (II) ${ }^{3)}$ the specific rotation did not correspond to that reported for roridine $\mathrm{E},[\alpha]_{\mathrm{D}}-16^{\circ} .^{3)}$ Hydrolysis of isororidin $\mathrm{E}$ gave the known verrucarol $^{4)}$ and a dicarboxylic acid, which was a stereoisomer at $\mathrm{C}-6^{\prime}$ and/or $\mathrm{C}-13^{\prime}$ of the corresponding acid of roridin $\mathrm{E}$ (II).

$7 \beta, 8 \beta$-Epoxyisororidin $\mathrm{E}$ (III) was obtained as colorless prisms: $\mathrm{C}_{29} \mathrm{H}_{36} \mathrm{O}_{9} ;$ m.p. $216 \sim 219^{\circ} \mathrm{C}$ (from acetone); $\mathrm{M}^{+} 528[\alpha]_{\mathrm{D}}^{24}-69.9^{\circ}\left(\mathrm{CHCl}_{3}\right)$; $\nu_{\max }^{\mathrm{OHO} 1_{3}} 3567(\mathrm{OH}), 1712(\mathrm{C}=\mathrm{O}), 1644(\mathrm{C}=\mathrm{C})$, and $1598 \mathrm{~cm}^{-1}(\mathrm{C}=\mathrm{C}) ; \lambda_{\max }^{\mathrm{EtOH}} 221 \mathrm{~nm}(\approx 26,300)$ and $262(16,700)$. NMR and hydrolytic studies clearly show that compound III has a $\beta$-epoxy function at $\mathrm{C}-7,8$ in the verrucarol moiety and a side chain similar to that of isororidin E (II). Therefore, this compound is represented by formula III.

$7 \beta, 8 \beta$-Epoxyroridin $\mathrm{H}$ (IV) was obtained as a colorless amorphous powder: $\mathrm{C}_{29} \mathrm{H}_{34} \mathrm{O}_{9} ; \mathrm{M}^{+}$ 526; $\nu_{\max }^{\mathrm{CHC} 13} 1717(\mathrm{C}=\mathrm{O}), 1646(\mathrm{C}=\mathrm{C})$, and $1601 \mathrm{~cm}^{-1}$ (C=C). $7 \beta, 8 \beta ; 2^{\prime}, 3^{\prime}$-Diepoxyroridin

Chart 1.

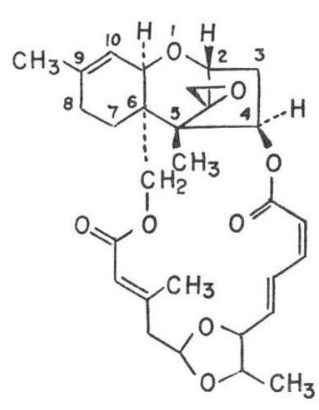

(1)

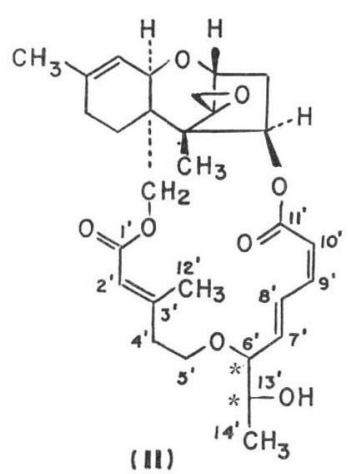

(II)

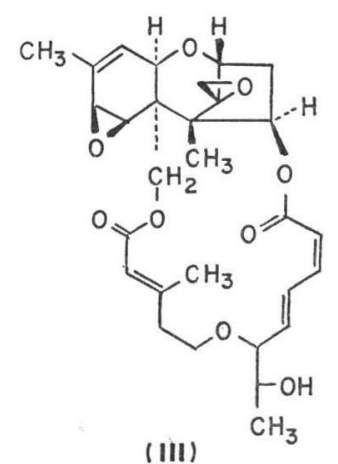

(III)

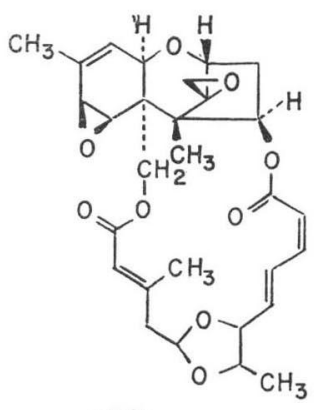

(IV)

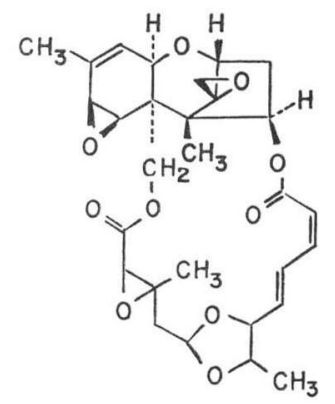

(v) 
$\mathrm{H}(\mathrm{V})$ was obtained as colorless prisms: $\mathrm{C}_{29} \mathrm{H}_{34^{-}}$ $\mathrm{O}_{10}$; m.p. $291 \sim 293^{\circ} \mathrm{C}$ (dec.) (sealed); $\mathrm{M}^{+} 542$; $\nu_{\max }^{\mathrm{CHC} 13} 1755(\mathrm{C}=\mathrm{O}), 1710(\mathrm{C}=\mathrm{O}), 1645(\mathrm{C}=\mathrm{C})$, and $1601 \mathrm{~cm}^{-1}(\mathrm{C}=\mathrm{C})$. The structures of IV and $\mathbf{V}$ were derived from ${ }^{1} \mathrm{H}$ NMR in conjuction with the ${ }^{13} \mathrm{C}$ FT NMR spectra.

During this work, we found that cis-relationship between $2^{\prime}-\mathrm{H}$ and $3^{\prime}-\mathrm{CH}_{3}$ in roridin $\mathrm{E}^{3)}$ and $\mathrm{H}^{2)}$ should be revised to trans-configuration from NMR studies; no NOE was observed between $3^{\prime}-\mathrm{CH}_{3}$ and $2^{\prime}-\mathrm{H}$, although NOE's were observed between $9-\mathrm{CH}_{3}$ and $10-\mathrm{H}(\mathrm{ca} .15 \%)$ in the compounds examined. Structural elucidation of the four new compounds $(\mathbf{I I} \sim \mathbf{V})$ will be described in a forthcoming paper.

Makoto Matsumoto Hrtoshi Minato NoBUO UOTANI KoIChi Matsumoto EIJ Kondo
Shionogi Research Laboratory Shionogi \& Co., Ltd.

Fukushima-ku, Osaka, 533

Japan

(Received March 30, 1977)

\section{References}

1) ТАмм, Сн.: The antibiotic complex of the verrucarins and roridins. Fortschr. Chem. Org. Naturst. 31: 63 117, 1974

2) Traxler, P. \& CH. TAMm: Die Struktur des Antibioticums Roridin H. Helv. Chim. Acta 53: $1846 \sim 1869,1970$

3) Traxler, P.; W. Zürcher \& Ch. TAmm: Die Struktur des Antibioticums Rorindin E. Helv. Chim. Acta 53: 2071 2085, 1970

4) Gutzwiller, J.; R. Mauli, H. P. Sigg \& Ch. TAмм: Die Konstitution von Verrucarol und Roridin C. Helv. Chim. Acta 47: 2234 2262, 1964 